\title{
KECERDASAN EMOSI DENGAN KEPEMIMPINAN TRANSFORMASIONAL MANAJER HRD DI JAWA TENGAH
}

\author{
Regina Tikva Kessek ${ }^{1}$ \\ Fakultas Psikologi, Universitas Kristen Satya Wacana \\ kessekregina@gmail.com \\ Sutarto Wijono ${ }^{2}$ \\ Fakultas Psikologi, Universitas Kristen Satya Wacana \\ wijonosutarto@gmail.com, sutartown@yahoo.com
}

\begin{abstract}
This study aimed to determine the relationship between Emotional Intelligence and HRD Manager Transformational Leadership in Central Java. The number of participants in this study was 47 HRD managers with data collection using purposive sampling and saturation sample techniques. This research used a correlation quantitative research methods. The Emotional Intelligence data collection tool was adapted from Goleman's theory (2014) by Leading Across London Corporate Creators and the Transformational Leadership scale was taken from the Multifactor Leadership Questionnaire (MLQ Form 6s) by Bass (2006). Data analysis used in this research was Pearson Product Moment with SPSS 23.0 for windows. The results obtained showed a significant and positive relationship between Emotional Intelligence and Transformational Leadership ( $r=0.599$; $p<0.05)$.
\end{abstract}

Keywords: emotional intelligence, HRD Manager, transformational leadership.

\begin{abstract}
Abstrak
Penelitian ini bertujuan untuk mengetahui hubungan antara Kecerdasan Emosi dengan Kepemimpinan Transformasional Manajer HRD di Jawa Tengah. Jumlah partisipan dalam penelitian ini adalah 47 manajer HRD dengan pengambilan data menggunakan teknik purposive sampling dan teknik sampel jenuh (saturation sample). Penelitian ini menggunakan metode penelitian kuantitatif korelasional. Alat pengumpulan data Kecerdasan Emosi diadaptasi dari teori Goleman (2014) oleh Leading Across London Corporate Creators dan skala Kepemimpinan Transformasional diambil dari Multifactor Leadership Questionnaire (MLQ Form 6s) oleh Bass (2006). Analisis data menggunakan Pearson Product Moment dengan SPSS 23.0 for windows. Hasil penelitian yang diperoleh menunjukkan adanya hubungan signifikan dan positif antara Kecerdasan Emosi dengan Kepemimpinan Transformasional $(r=0,599 ; \mathrm{p}<0,05)$.
\end{abstract}

Kata kunci: kecerdasan emosi, kepemimpinan transformasional, Manajer HRD. 


\section{PENDAHULUAN}

Manusia merupakan makhluk sosial yang diciptakan untuk dapat beradaptasi serta membangun hubungan dengan individu lainnya. Salah satu cara membangun hubungan dengan sesama manusia yaitu lewat sebuah organisasi. Secara umum organisasi merupakan komponen yang di dalamnya saling berkaitan satu dengan yang lainnya dan dalam organisasi pula terdapat visi, misi serta budaya dan iklim organisasi yang menentukan arah dan tujuan organisasi tersebut (Yuliana, 2012). Sebuah organisasi dapat berjalan dengan baik apabila orang yang bekerja dapat berfungsi dengan baik pula. Dan dalam sebuah organisasi dibutuhkan seorang pemimpin yang mengarahkan timnya untuk mencapai tujuan bersama.

Dalam penelitian ini, penulis melakukan penelitian terhadap para pemimpin yang difokuskan pada manajer HRD di Jawa Tengah. Sementara itu, organisasi-organisasi yang akan diteliti bergerak dalam bidang manufaktur, usaha, jasa, dan pelayanan masyarakat. Dalam suatu kesempatan, penulis mengamati adanya jabatan-jabatan manajerial pemimpin untuk diteliti dari beberapa organisasi tersebut. Penulis tertarik untuk melakukan penelitian terhadap organisasi-organisasi tersebut karena berbicara mengenai kepemimpinan transformasional dalam organisasi pasti memiliki keunikannya masing-masing. Kemudian, dalam pengamatan sementara terhadap beberapa manajer HRD yang ada di Jawa Tengah penulis menemukan adanya fenomena yang terkait dengan gaya kepemimpinan transformasional.

Pada kesempatan ini, penulis ingin mengetahui lebih lanjut fenomena yang terkait dengan kepemimpinan transformasional pada beberapa organisasi yang akan diteliti. Penulis memiliki kesempatan untuk mewawancarai seorang High Senior Manager Human Resource Development dan dari wawancara tersebut penulis menyimpulkan adanya fenomena-fenomena di antara para manajer HRD di beberapa organisasi yang akan penulis teliti. Kemudian, dari hasil informasi yang diperoleh bahwa sebagian besar manajer HRD tersebut memiliki karakteristik yang berkaitan dengan aspek-aspek kepemimpinan transformasional diantaranya mereka memiliki pengaruh yang kuat dan visi yang jelas dalam kepemimpinannya, mereka memotivasi orang-orang yang dipimpin, mereka mendorong untuk memunculkan ide-ide baru bagi stafnya, namun ada beberapa pemimpin yang masih kurang dalam pemberian mentoring kepada stafnya, ada juga yang masih belum bisa memberikan umpan balik yang konstruktif. Atas dasar fenomena tersebut dapat dikatakan bahwa ada masalah yang terkait dengan kepemimpinan transformasional.

Munculnya fenomena di atas, maka penelitian tentang kepemimpinan transformasional perlu dilakukan di berbagai organisasi atau perusahaan yang ada di Jawa Tengah. Dalam hal 
ini, ada beberapa temuan yang mendukung untuk ditelitinya kepemimpinan transformasional tersebut seperti yang diungkapkan oleh Spano-szekely (2016), yang mengatakan jika dibandingkan dengan kepemimpinan lainnya, kualitas kepemimpinan transformasional dapat mempromosikan lingkungan kerja yang sehat dan menghasilkan kepuasan, retensi, dan efektivitas pengikut yang lebih besar. Hal tersebut juga didukung oleh temuan Baba (2019), yang mengatakan bahwa kepemimpinan transformasional merupakan suatu perilaku manajerial yang paling efektif, dimana seorang pemimpin dapat membangun hubungan positif dengan orang yang dipimpin untuk bergerak dari kinerja yang lebih rendah ke kinerja yang lebih tinggi.

Dengan adanya penelitian-penelitian sebelumnya, menjelaskan bahwa kepemimpinan transformasional memiliki dampak positif maupun negatif bagi organisasi. Seperti temuan yang dilakukan oleh Spano-szekely (2016), menjelaskan bahwa dampak positif yang muncul yaitu dengan adanya pemimpin transformasional maka dapat mendorong antusias di antara karyawan organisasi untuk memanfaatkan nilai-nilai yang mereka tempatkan pada tujuan dan makna pekerjaan mereka dan pada kinerja proyek aktual. Hal tersebut juga dapat dilihat dengan dampak positif dari kepemimpinan transformasional yang dijelaskan oleh Lam dan O'Higgins (2013), yaitu lewat kehadiran seorang pemimpin transformasional, maka ia dapat mempengaruhi perilaku karyawan lainnya untuk mencapai tujuan organisasi (Hunitie, 2016). Sedangkan, dampak negatif yang terjadi berdasarkan temuan Spano-szekely (2016), dapat berupa bias monometode dan perubahan laporan diri reaktif, yang menjadi ancaman terhadap validitas penelitiannya yang terkait dengan kepemimpinan transformasional. Hal tersebut juga didukung oleh pernyataan Duckett dan Macfarlane (2006), yaitu lewat intervensi yang dilakukan secara tertutup dan eksplisit, dapat mengakibatkan perusahaan mengalami turn-over di beberapa bagian manajemen dan menghasilkan dampak negatif terhadap kepemimpinan transformasional.

Pada dasarnya pemimpin harus membantu timnya menemukan jalan untuk mencapai tujuan yang mereka inginkan dan membantu mereka dalam proses yang akan dilewati di sebuah organisasi. Untuk mendukung hal tersebut, maka ada beberapa faktor yang memengaruhi kepemimpinan seperti yang telah dijelaskan oleh Dulewicz dan Higgs (2003), yang menunjukkan bahwa ada empat faktor yang memengaruhi kepemimpinan transformasional yaitu kognitif, perilaku, emosional, motivasi (dalam Turner, 2005). Hasil temuan tersebut diperkuat oleh Goleman (1998), bahwa faktor kecerdasan emosi merupakan prasyarat untuk kepemimpinan yang sukses. Kemudian individu yang memiliki kecerdasan emosi yang tinggi akan lebih cenderung menggunakan perilaku transformasional dalam kepemimpinannya 
(Barling, Slater, \& Kevin Kelloway, 2000).

Dalam penelitian ini, penulis mengambil kecerdasan emosi untuk melihat hubungan yang dapat terjadi jika dikaitkan dengan kepemimpinan transformasional. Seiring berkembangnya jaman, kecerdasan emosi menjadi salah satu pengaruh dalam terbentuknya kepemimpinan transformasional. Kecerdasan emosi merupakan hal yang penting untuk diteliti pada beberapa organisasi yang akan penulis teliti. Hal tersebut diperjelas oleh Duckett dan Macfarlane (2006), bahwa seseorang dengan kecerdasan emosi yang tinggi memiliki kemampuan untuk memahami diri sendiri dan orang lain dan untuk menyesuaikan perilaku dengan konteks tertentu. Dengan semakin memahami dan mengekspresikan emosi diri sendiri dan emosi orang lain, maka para manajer HRD yang ada di beberapa perusahaan di Jawa Tengah berpeluang untuk menghasilkan kepemimpinan transformasional yang tinggi dan lebih baik dari sebelumnya. Pernyataan tersebut didukung oleh Potter, Egbelakin, Zealand, dan Balaei (2018), bahwa untuk berhasil memimpin sekelompok orang yang beragam budayanya, maka diperlukan tingkat kecerdasan emosi yang lebih tinggi.

Dengan adanya penelitian yang dilakukan selama kurang lebih 10 tahun terakhir ditemukan bahwa terdapat hubungan positif maupun negatif antara kecerdasan emosi dan kepemimpinan transformasional. Salah satunya temuan Spano-szekely (2016), menjelaskan bahwa adanya hubungan positif dan signifikan mengenai kecerdasan emosi dan kepemimpinan transformasional dengan pendidikan lanjutan dan sertifikasi administrasi. Hal tersebut pun mendukung penelitian Baba (2019), yang menemukan bahwa ada hubungan yang signifikan dan langsung antara kecerdasan emosi para pemimpin dan gaya kepemimpinan transformasional. Selain itu, hal yang sama didukung oleh Chan, Omar, Ahmad, Zaman, dan Idrus (2018), bahwa terdapat hubungan positif antara kecerdasan emosi dengan kepemimpinan transformasional yang dilakukan. Sedangkan penelitian lainnya yang dilakukan oleh Hunitie (2016), juga menjelaskan bahwa ada hubungan yang signifikan antara memahami emosi dan motivasi inspirasional serta antara menggunakan emosi dan pengaruh ideal dan pertimbangan individu. Kemudian dalam penelitian yang dilakukan oleh Weinberger (2009), menjelaskan bahwa tidak terdapat hubungan antara kecerdasan emosi manajer dan gaya kepemimpinan atau persepsi efektivitas pemimpin. Temuan tersebut pun didukung oleh Genderen (2012), yang menunjukkan sebuah hubungan negatif antara kecerdasan emosi dengan kepemimpinan transformasional pada manajer Rusia (dalam Hunitie, 2016). Sedangkan penelitian oleh Asmadi dan Syairudin (2015), menjelaskan tidak adanya keterkaitan antara kecerdasan emosi dengan kepemimpinan transformasional dan mengatakan bahwa kepemimpinan 
transformasional tidak memberi pengaruh menurunkan atau menaikkan hubungan langsung kecerdasan emosi.

Dalam hal ini, penulis tertarik untuk meneliti tentang hubungan antara kecerdasan emosi dengan kepemimpinan transformasional karena penulis melihat masih terdapat berbagai perbedaan dari hasil penelitian sebelumnya. Ketika penulis mencermati lebih jauh, terdapat perbedaan yang penulis temukan dari segi teori yang digunakan dalam meneliti kecerdasan emosi dengan kepemimpinan transformasional. Dalam penelitian ini penulis menggunakan teori kecerdasan emosi oleh Goleman (1995), yang mengatakan bahwa orang yang cerdas secara emosional memiliki kemampuan untuk mengendalikan impuls emosional mereka, memiliki kesadaran diri untuk mengetahui apa yang mereka rasakan, dan mampu memikirkan dan mengekspresikan emosinya. (Ugoani, Amu, \& Kalu, 2015). Kemudian teori kepemimpinan transformasional yang digunakan diambil dari Bass dan Riggio (2006), yaitu pemimpin transformasional adalah mereka yang merangsang dan menginspirasi pengikut untuk mencapai hasil yang luar biasa dalam prosesnya, serta mengembangkan kapasitas kepemimpinan mereka sendiri. Berdasarkan latar belakang yang telah dipaparkan di atas, maka penulis mengajukan hipotesis dalam penelitian ini yaitu terdapat hubungan antara kecerdasan emosi dengan kepemimpinan transformasional manajer HRD di Jawa Tengah.

\section{METODE}

Pendekatan yang digunakan dalam penelitian ini yaitu pendekatan kuantitatif. Penelitian ini menggunakan jenis penelitian korelasional. Adapun variabel yang akan diteliti yaitu kecerdasan emosi sebagai variabel independen $(\mathrm{X})$ dan kepemimpinan transformasional sebagai variabel dependen (Y). Sugiyanto (2008: 117) mengatakan bahwa populasi adalah wilayah generalisasi yang terdiri dari objek atau subjek, demikian pula karakteristik dari objek atau subjek tertentu (dalam Budiana, 2009). Dari populasi ini dapat diambil sampel yang diharapkan mampu mewakili populasi. Populasi yang digunakan sebagai sampel dalam penelitian ini adalah total keseluruhan manajer HRD di berbagai perusahaan di Jawa Tengah.

Teknik pengambilan sampel yang digunakan dalam penelitian ini adalah purposive sampling, yaitu teknik yang menggunakan berbagai kriteria atau pertimbangan tertentu dalam pengambilan sampelnya (Dewi, Handayani, \& Nuzula, 2014). Selain itu, penelitian ini menggunakan teknik sampling jenuh atau sensus. Mengenai hal itu, Sugiyono (2010: 85) menjelaskan bahwa sampling jenuh adalah teknik penentuan sampel bila semua anggota populasi digunakan sebagai sampel dan teknik ini digunakan bila jumlah populasi relatif kecil. 
Tahap dalam proses pengambilan data dilakukan melalui 2 skala psikologis yang pertama yaitu skala kecerdasan emosi yang diadaptasi dari teori Goleman (2014) oleh Leading Across London Corporate Creators. Skala kecerdasan emosi tersebut terdiri dari 50 aitem dan menggunakan skala Likert dengan 4 pilihan jawaban yaitu: Sangat Setuju, Setuju, Tidak Setuju, Sangat Tidak Setuju.

Kemudian skala kepemimpinan transformasional menggunakan Multifactor Leadership Questionnaire (MLQ Form 6s) oleh Bass (2006). Skala tersebut terdiri dari 12 aitem kemudian dimodifikasi oleh penulis menjadi 20 aitem. Skala ini menggunakan skala Likert dengan 4 pilihan jawaban yaitu: Sangat Setuju, Setuju, Tidak Setuju, Sangat Tidak Setuju.

Sebelum melakukan pengambilan data kepada para manajer di beberapa perusahaan di Jawa Tengah, penulis memodifikasi dan mengadaptasi aitem dari 2 skala psikologis yang digunakan dalam penelitian ini. Apabila sudah tidak ada kesalahan ataupun kendala terhadap skala psikologis, maka penulis melakukan konsultasi dengan dosen pembimbing. Selanjutnya, skala psikologis tersebut disebarkan lewat google form sesuai dengan kebutuhan pengambilan data kepada responden yang akan diteliti.

\section{HASIL DAN PEMBAHASAN}

\section{Analisis Deskriptif}

Kecerdasan Emosi

Tabel 1.

Kategorisasi Kecerdasan Emosi

\begin{tabular}{llllll}
\hline Interval & Kategori & Frequency & Percent & Valid Percent & $\begin{array}{l}\text { Cumulative } \\
\text { Percent }\end{array}$ \\
\hline $102 \leq \mathrm{x}<118$ & Rendah & 7 & 14,9 & 14,9 & 14,9 \\
$118 \leq \mathrm{x}<134$ & Sedang & 34 & 72,3 & 72,3 & 87,2 \\
$134 \leq \mathrm{x} \leq 150$ & Tinggi & 6 & 12,8 & 12,8 & 100,0 \\
\cline { 2 - 5 } & Total & 47 & 100,0 & 100,0 & \\
\hline $\mathrm{SD}=10,71$ & Max $=150$ & Min $=102$ & Mean $=120,83$ & \\
\hline
\end{tabular}

Berdasarkan tabel di atas, dapat dilihat bahwa 7 subjek memiliki skor rendah dengan persentase 14,9\%, 34 subjek memiliki skor sedang dengan persentase $72,3 \%$ dan terdapat 6 subjek yang memiliki skor tinggi dengan persentase $12,8 \%$. Selain itu, rata-rata yang diperoleh sebesar 120,83 dan dapat dikatakan bahwa rata-rata kecerdasan emosi berada pada kategori 
sedang. Skor yang diperoleh subjek bergerak dari skor minimum sebesar 102 sampai dengan skor maksimum 150 dengan standar deviasi 10,71.

Kepemimpinan Transformasional

Tabel 2.

Kategorisasi Kepemimpinan Transformasional

\begin{tabular}{llllll}
\hline Interval & Kategori & Frequency & Percent & Valid Percent & $\begin{array}{l}\text { Cumulative } \\
\text { Percent }\end{array}$ \\
\hline $46,9 \leq \mathrm{x}<55,6$ & Rendah & 3 & 6,4 & 6,4 & 6,4 \\
$55,6 \leq \mathrm{x}<66,3$ & Sedang & 38 & 80,9 & 80,9 & 87,2 \\
$66,3 \leq \mathrm{x} \leq 76$ & Tinggi & 6 & 12,8 & 12,8 & 100,0 \\
\cline { 2 - 5 } & Total & 47 & 100,0 & 100,0 & \\
\cline { 2 - 5 } $\mathrm{SD}=5,797$ & Max $=76$ & Min $=47$ & Mean $=60,45$ & & \\
\hline
\end{tabular}

Berdasarkan tabel di atas, terlihat bahwa 3 subjek memiliki skor rendah dengan presentase 6,4\%, 38 subjek memiliki skor sedang dengan persentase 80,9\% dan 6 subjek memiliki skor tinggi dengan persentase $12,8 \%$. Kemudian, dari hasil rata-rata yang diperoleh sebesar 60,45 dapat dikatakan bahwa kepemimpinan transformasional berada pada kategori sedang. Skor yang diperoleh subjek bergerak dari skor minimum sebesar 47 sampai dengan skor maximum 76 dengan standar deviasi 5,797.

\section{Uji Reliabilitas}

Berdasarkan pengujian seleksi aitem dan reliabilitas skala kecerdasan emosi yang terdiri dari 50 aitem, maka diperoleh beberapa aitem yang gugur sebanyak 12 aitem yang gugur dengan koefisien korelasi yang bergerak antara 0,300 - 0,647. Proses pengujian reliabilitas ini menggunakan teknik koefisien Alpha Cronbach dengan koefisien Alpha pada skala kecerdasan emosi sebesar 0,908. Dalam hal ini, skala kecerdasan emosi dapat dikatakan reliabel. Sementara itu, berdasarkan pengujian seleksi aitem dan reliabilitas skala kepemimpinan transformasional yang terdiri dari 20 aitem, diperoleh aitem yang gugur sebanyak 1 aitem dengan koefisien korelasi yang bergerak antara 0,328 - 0,767. Proses pengujian reliabilitas ini menggunakan teknik koefisien Alpha Cronbach dengan koefisien Alpha pada skala kepemimpinan transformasional sebesar 0,895. Dengan kata lain, skala kepemimpinan transformasional dapat dikatakan reliabel. 


\section{Uji Asumsi}

Uji Normalitas

Penelitian ini menggunakan uji normalitas dengan tujuan untuk menguji apakah data yang digunakan dalam penelitian berdistribusi normal atau tidak. Data dapat dikatakan normal jika nilai signifikansi lebih besar dari $0,05(\mathrm{p}>0,05)$ yang diperoleh dari hasil analisa menggunakan SPSS 23.0 for windows.

Berdasarkan hasil uji normalitas yang diperoleh, diketahui bahwa hasil perhitungan uji Kolmogorov-smirnov Z memperoleh nilai signifikansi Asymp. Sig (2-tailed) sebesar 0,200 (p $>0,05)$. Maka sesuai dengan hasil perhitungan tersebut, dapat disimpulkan bahwa data berdistribusi normal.

Uji Linearitas

Berdasarkan hasil perhitungan di SPSS 23.0 for windows, menunjukkan bahwa ada hubungan yang linear secara signifikan antara variabel kecerdasan emosi dan kepemimpinan transformasional dengan Deviation from Linearity sebesar 0,711 $(\mathrm{p}>0,05)$ dan nilai signifikansi sebesar 0,791 ( $\mathrm{p}>0,05)$.

Uji Korelasi

Tabel Hasil Uji Korelasi Kecerdasan Emosi dan Kepemimpinan Tranformasional

\section{Correlations}

\begin{tabular}{llll}
\hline & & $\begin{array}{l}\text { Kecerdasan } \\
\text { Emosi }\end{array}$ & $\begin{array}{l}\text { Kepemimpinan } \\
\text { Transformasional }\end{array}$ \\
\hline Kecerdasan Emosi & Pearson Correlation & 1 &, $599^{* *}$ \\
& Sig. (2-tailed) & & 000 \\
& $\mathrm{~N}$ & 47 & 47 \\
\hline Kepemimpinan & Pearson Correlation &, $599^{* *}$ & 1 \\
Transformasional & Sig. (2-tailed) &, 000 & 47 \\
& $\mathrm{~N}$ & 47 & 47 \\
\hline
\end{tabular}

**. Correlation is significant at the 0.01 level (2-tailed)

Berdasarkan hasil pengujian yang telah dilakukan, maka diperoleh korelasi sebesar $\mathrm{r}=$ $0,599(\mathrm{p}<0,05)$. Hasil analisis statistik yang diperoleh menunjukkan adanya hubungan positif dan signifikan antara Kecerdasan Emosi dan Kepemimpinan transformasional pada manajer HRD di Jawa Tengah, yang artinya bahwa hipotesis dalam penelitian ini diterima.

Hipotesis penelitian berbunyi bahwa ada hubungan signifikan antara Kecerdasan Emosi dan Kepemimpinan Transformasional. Hasil penelitian menunjukkan ada hubungan signifikan dan positif antara kecerdasan emosi dan kepemimpinan transformasional atau $r=0,599(p<$ 0,05). Dengan kata lain semakin tinggi kecerdasan emosi maka semakin tinggi pula 
kepemimpinan transformasional. Dengan demikian, dapat dikatakan bahwa variabel kecerdasan emosi mempunyai peran terhadap meningkatnya kepemimpinan transformasional.

Berdasarkan hasil yang diperoleh maka penulis menduga ada beberapa kemungkinan yang menyebabkan adanya hubungan signifikan tersebut. Pertama, sebagian besar manajer HRD yang ada di berbagai perusahaan tersebut memiliki kecerdasan emosi yang dapat digunakan sebagai dasar dalam memimpin stafnya sehingga hal tersebut dapat mewujudkan adanya kepemimpinan transformasional. Hal tersebut didukung oleh temuan Duckett dan Macfarlane (2006), yang menyatakan bahwa individu dengan kecerdasan emosi yang tinggi dapat menunjukkan kompetensi sosial dan pribadi untuk dapat berorientasi pada kepemimpinan transformasional dengan penekanan pada motivasi dan mempengaruhi orang lain. Kedua, kecerdasan emosi yang ditunjukkan oleh para manajer bisa melalui pengelolaan emosi dalam mengambil suatu keputusan sehingga hal tersebut tercermin dalam kepemimpinan mereka. Hal itu diperkuat dengan pernyataan Cherniss dan Goleman (2001), yang menemukan bahwa kecerdasan emosi berkontribusi sekitar 90\% dalam keberhasilan sebuah kepemimpinan. Ketiga, para manajer menyadari bahwa kecerdasan emosi yang mereka miliki dapat membangun kepercayaan para stafnya dan hal itu dapat memungkinkan para pemimpin memiliki makna yang positif dalam mencapai tujuan organisasi sehingga kepemimpinan yang dijalankan menjadi kepemimpinan yang transformasional. Hal tersebut sejalan dengan penelitian Ugoani, J.N.N., Amu, C.U., dan Kalu, E. O. (2015), yang mengatakan bahwa manajemen emosional mempromosikan efek positif dan kepercayaan pengikut, yaitu pemimpin yang sadar diri memiliki tujuan dan makna yang lebih besar, orang yang terampil dalam kecerdasan emosi sering menempatkan kebutuhan orang lain diatas kebutuhan mereka sendiri.

Sementara itu penulis mencoba untuk menganalisis kembali bahwa masing-masing aspek dari kecerdasan emosi memiliki korelasi yang signifikan dan positif dengan kepemimpinan transformasional. Dalam hal ini, aspek yang pertama yaitu kesadaran diri yang ditunjukan dengan $\mathrm{r}=0,635(\mathrm{p}<0,05)$. Artinya, semakin tinggi kesadaran diri seorang pemimpin maka semakin tinggi pula kepemimpinan transformasional. Dengan kata lain, kesadaran diri memberikan peran dalam peningkatan kepemimpinan transformasional. Hasil penelitian ini memungkinkan sebagian besar manajer memiliki kesadaran diri yang kuat dalam dirinya sehingga dapat membuat kepemimpinan transformasional menjadi nyata dalam kehidupan sehari-hari. Hal ini didukung oleh penelitian Tekleab, Sims, Yun, Tesluk, dan Cox (2008), yang mengatakan bahwa penelitian tentang kepemimpinan telah menghasilkan 
hubungan antara kesadaran diri kepemimpinan transformasional dan dioperasikan dalam hal kesadaran diri dan kinerja pemimpin. Kemudian yang kedua yaitu aspek mengelola diri yang menunjukkan hubungan signifikan dan positif dengan $r=0,355(\mathrm{p}<0,05)$ yang artinya pengelolaan diri memberi peran terhadap kepemimpinan transformasional. Hal ini dimungkinkan karena sebagian manajer memiliki pengelolaan diri yang baik untuk melakukan aktivitas sehingga hal ini dapat mendukung kemampuannya dalam memimpin sebagai pemimpin yang transformasional. Selanjutnya, aspek yang ketiga yaitu memotivasi diri dengan $\mathrm{r}=0,476(\mathrm{p}<0,05)$ maka diperoleh semakin tinggi motivasi diri seorang pemimpin maka ia akan semakin tinggi dalam menghasilkan kepemimpinan transformasionalnya. Artinya motivasi diri mempunyai peran terhadap kepemimpinan transformasional dimana sebagian manajer menganggap bahwa mereka memiliki motivasi diri dalam mengaplikasikan kepemimpinan transformasional mereka. Kemudian, aspek yang keempat yaitu empati (mengenali emosi orang lain) yang memperoleh $r=0,585(p<0,05)$ artinya empati memiliki peran terhadap kepemimpinan transformasional. Dengan kata lain, ada kemungkinan bahwa sebagian manajer yang memiliki empati yang tinggi terdapat kecenderungan bahwa mereka dikategorikan sebagai orang yang memiliki kecerdasan emosi yang tinggi pula, sehingga membuat mereka dapat mewujudkan kepemimpinan transformasionalnya. Hal ini sejalan dengan temuan Duckett dan Macfarlane (2006), bahwa seseorang dengan kecerdasan emosi yang tinggi memiliki kemampuan untuk memahami diri sendiri dan memahami orang lain atau sikap empati untuk menyesuaikan dengan perilaku kepemimpinan transformasional. Kemudian, aspek terakhir mengenai mengelola hubungan yang memperoleh $\mathrm{r}$ sebesar 0,660 (p $<0,05)$. Dalam hal ini, semakin tinggi cara mengelola hubungan dengan orang lain maka semakin tinggi pula kepemimpinan transformasional yang dihasilkan. Artinya sebagian manajer yang mampu membangun hubungan yang baik terhadap orang-orang yang dipimpin, dapat memberikan pengaruh hubungan yang bersifat transformasional dalam kepemimpinannya.

Dalam penelitian ini juga ditemukan bahwa kecerdasan emosi masuk dalam kategori tingkat sedang atau rata-rata yang memperoleh persentase sebesar $72,3 \%$ dan subjek yang rendah memiliki presentase 14,9\% sedangkan subjek yang masuk kategori tinggi memperoleh presentase sebesar $12,8 \%$. Kemudian, dilihat dari hasil analisis yang telah dilakukan didapatkan bahwa kepemimpinan transformasional masuk dalam kategori sedang atau rata-rata dengan persentase yang diperoleh sebesar 80,9\%, sedangkan kategori yang rendah memperoleh persentase $6,4 \%$ dan yang tinggi sebesar $12,8 \%$. Dari hasil yang diperoleh tersebut, maka dapat 
dikatakan bahwa kecerdasan emosi dan kepemimpinan transformasional dari masing-masing subjek penelitian termasuk dalam kategori sedang atau rata-rata.

\section{SIMPULAN}

Penelitian ini menunjukkan bahwa ada hubungan yang signifikan dan positif antara Kecerdasan Emosi dengan Kepemimpinan Transformasional manajer HRD di Jawa Tengah. Saran yang dapat dikemukakan oleh penulis adalah sebagai berikut: bagi perusahaan, pihak manajemen dapat memberikan kesempatan kepada para manajer untuk mengembangkan kecerdasan emosi dalam melakukan tugas dan pekerjaannya agar dapat mewujudkan kepemimpinan transformasionalnya. Hal tersebut bisa dipraktekkan melalui penyediaan fasilitas yang ada dalam organisasi seperti tempat untuk melakukan Leadership Group Discussion (LGD) dan/atau diskusi kelompok. Bagi manajer, para manajer dapat memanfaatkan peluang yang ada dalam organisasi untuk mengembangkan kecerdasan emosi dalam meningkatkan kepemimpinan transformasional guna menciptakan hubungan dan kepercayaan yang positif dengan para staf. Hal itu dapat dilakukan melalui role play dan simulasi. Bagi peneliti selanjutnya, untuk penulis selanjutnya disarankan dapat menggunakan middle manager sebagai respondennya dan penulis dapat memperluas populasi penelitian. Selain itu, penulis perlu menambah faktor demografi untuk memperkuat hasil penelitian..

\section{DAFTAR PUSTAKA}

Asmadi, D., \& Syairudin, B. (2015). Kontribusi kecerdasan emosional dan kecerdasan spiritual terhadap kinerja karyawan yang dimoderasi kepemimpinan transformasional. Prosiding Seminar Nasional Manajemen Teknologi XXII, 1-10.

Baba, M. M. (2019). Emotional intelligence and transformational leadership among academic leaders in institutions of higher learning. Global Business Review.

Barling, J., Slater, F., \& Kevin Kelloway, E. (2000). Transformational leadership and emotional intelligence: An exploratory study. Leadership \& Organization Development Journal, 21(3), 157-161.

Bass, B. M., \& Riggio, R. E. (2006). Transformational leadership (2nd ed). Lawrence Erlbaum Associates Publishers.

Budiana, N. (2009). Fakultas keguruan dan ilmu pendidikan Universitas Muhammadiyah Surakarta. Journal, 1-15.

Chan, S. W., Omar, S. S., Ahmad, F., Zaman, I., \& Idrus, N. (2018). Emotional intelligence 
and transformational leadership among managers in manufacturing companies. International Journal of Engineering and Technology, 7(21), 1-4.

Dewi, I. R., Handayani, S. R., \& Nuzula, N. F. (2014). Pengaruh struktur modal terhadap nilai perusahaan. 17(1).

Duckett, H., \& Macfarlane, E. (2006). Emotional intelligence and transformational leadership in retailing. Leadership \& Organization Development Journal, 24(6), 309-317.

Hunitie, M. (2016). Emotional intelligence and transformational leadership style Empirical Research on Public Schools in Jordan, 9(9), 168-175.

Potter, E. M., Egbelakin, T., Zealand, N., \& Balaei, B. (2018). Emotional intelligence and transformational leadership behaviours of construction project managers. Journal of Financial Management of Property and Construction Article information.

Spano-szekely, L. (2016). Emotional Intelligence and Transformational Leadership in Nurse Managers, 46(2), 101-108.

Tekleab, A. G., Sims, H. P., Yun, S., Tesluk, P. E., \& Cox, J. (2008). Are we on the same page?: Effects of self-awareness of empowering and transformational leadership. Journal of Leadership and Organizational Studies, 14(3), 185-201.

Turner, R. (2005). The project manager's leadership style as a success factor on projects: A literature review. Project Management Journal, 36(2), 49-6.

Ugoani, J. N. N., Amu, C. U., \& Kalu, E. O. (2015). Dimensions of emotional intelligence and transformational leadership: A correlation analysis. Independent Journal of Management \& Production, 6(2), 563-584.

Weinberger, L. A. (2009). Emotional intelligence, leadership style, and perceived leadership effectiveness. Advances in Developing Human Resources, 11(6), 747-772.

Yuliana, R. (2012). Peran komunikasi dalam organisasi. STIE Semarang, 4(3), 52-58. 